\title{
Family participation to elderly rehabilitation with femoral fracture
}

\author{
Participação familiar para a reabilitação de idosos com fratura de fêmur \\ Participación de la familia para la rehabilitación de ancianos con fractura de fémur
}

\section{Marla Andréia Garcia de Avila', Gilberto José Cação Pereira", Silvia Cristina Mangini Bocchi'}

'Universidade Estadual Paulista, School of Medicine of Botucatu, Department of Nursing. Botucatu, São Paulo, Brazil.

"Universidade Estadual Paulista, School of Medicine of Botucatu, Department of Surgery and Orthopedics. Botucatu, São Paulo, Brazil.

\section{How to cite this article:}

Avila MAG, Pereira GJC, Bocchi SCM. Family participation to elderly rehabilitation with femoral fracture. Rev Bras Enferm. 2015;68(5):601-7. DOI: http://dx.doi.org/10.1590/0034-7167.2015680517i

Submission: 12-15-2014 Approval: 07-13-2015

\begin{abstract}
Objective: verify if the mode of care adopted by caregivers favored functional independence recovery by elderly with and without the presence of nervous system disease and mental and behavioral disorders; and, if disease interfered with their functional independence. Method: transversal study, with 12-month follow-up of 89 Brazilian elders ( $\geq 60$ years) after proximal femoral surgery, and their family caregiver. Results: the Functional Independence Measure scores decreased by 0.7 points per year of life, and in the case of presenting nervous system disease and mental and behavioral disorders, this loss amounted to 20.5 points. Conclusion: The incentive to ambulate increased by 18.8 for self-care, 12.8 for self-care, and 11.5 for leisure activities on the Functional Independence Measure. Encouraging movement and ambulation, self-care and leisure activities, especially with those elderly with nervous system diseases and mental and behavioral disorders, is recommended.
\end{abstract}

Key words: Aged; Caregivers; Femoral Fractures.

\section{RESUMO}

Objetivo: verificar se o modo de cuidar adotado pelos cuidadores favoreceu a recuperação da independência funcional dos idosos com e sem a presença de doença no sistema nervoso e transtornos mentais e comportamentais e se doenças interferiram na independência funcional. Método: estudo transversal, com seguimento por 12 meses de 89 idosos brasileiros ( $\geq 60$ anos), submetidos à cirurgia de fêmur proximal e seus cuidadores familiares. Resultados: os escores da Medida de Independência Funcional diminuíram 0,7 pontos por ano vivido e no caso de apresentar doença no sistema nervoso e transtorno mental e comportamental essa perda elevou-se para 20,5 pontos. O incentivo à deambulação aumentou 18,9, ao autocuidado 12,8 e ao lazer 11,5 pontos da Medida de Independência Funcional. Conclusão: recomenda-se o incentivo à movimentação e à deambulação, ao autocuidado e às atividades de lazer, principalmente naqueles idosos com doenças nos sistema nervoso e transtorno mental e comportamental.

Descritores: Idosos; Cuidadores; Fraturas do Fêmur.

\section{RESUMEN}

Objetivo: verificar si el modo de cuidar adoptado por los cuidadores favoreció la recuperación de la independencia funcional de los ancianos con y sin la presencia de enfermedad en el sistema nervioso y trastornos mentales y comportamentales y si enfermedades interfirieron en la independencia funcional. Método: estudio trasversal, con seguimiento por 12 meses de 89 ancianos brasileños ( $\geq 60$ años), sometidos a cirugía de fémur proximal y sus cuidadores familiares. Resultados: los scores de la Medida de Independencia Funcional disminuyeron 0,7 puntos por año vivido y, en el caso de enfermedad en el sistema nervioso y trastorno mental y comportamental, esa pérdida aumentó para 20,5 puntos. El incentivo a la deambulación aumentó 18,9, al autocuidado 12,8 y al ocio 11,5 puntos de la Medida de Independencia Funcional. Conclusión: se recomienda el incentivo al movimiento y a la deambulación, al autocuidado y a las actividades de ocio, principalmente en aquellos ancianos con enfermedades en el sistema nervioso y trastorno mental y comportamental.

Palabras clave: Anciano; Cuidadores; Fracturas del Fémur. 


\section{INTRODUCTION}

The falls following fractures of the proximal femur of elderly people have been identified as one of the principal causes of functional limitations, temporary or permanent, as well being an object of study not only in Brazil(1-2), but also in other countries, such as France ${ }^{(3)}$, Japan ${ }^{(4)}$ and the United States of America ${ }^{(5)}$. Within Brazil, between 2006 and 2008, proximal femoral fractures represented one percent of the hospitalizations of elderly receiving care from the Sistema Único de Saúde Brasileiro (Brazilian Unified Health System - SUS) ${ }^{(6)}$.

These consequences of falls range from the fear of a new event, experiencing clinical complications due to surgical complications or comorbidities, including the loss of independence and death. Additionally, in the majority of cases, there is a requirement for new family arrangements to meet the needs of the elderly.

It is known that the continuity of care for the elderly in their homes is critical for successful treatment and recovery of functional independence, and this task is a challenge for family caregivers, who perform this care with or without support ${ }^{(7)}$.

The performance of this role generates caregiver role strain, requiring coping strategies ${ }^{(8)}$, such as learning new skills related to care $^{(9)}$. The relationship between the activities inherent in the act of care and the level of dependency of each particular person requires different forms of training, guidance and monitoring of the caregiver, aiming to preserve her health and to ensure proper performance of her function ${ }^{(10)}$.

To prepare for hospital discharge of the binomial dependent elderly-family caregiver contributes to minimizing the caregiver role strain and to the improvement of the caregiver role performance ${ }^{(11)}$. This is because the lack of familiarity regarding necessary care can lead to health risks for the elderly, especially in cases of recurrence of falls ${ }^{(12)}$, as well as illness in the caregiver herself.

Caregivers of the elderly that count on the availability of social support, during the rehabilitation process at home after surgery for proximal femoral fracture, they presented better role performance when caregiver role strain was decreased. This support, however, was not shown to be sufficient for the caregiver to completely deconstruct the negative perception of her general and mental health, even in situations in which there was a reduction in dependence on the care of family members for activities of daily living of the elderly ${ }^{(11)}$.

It is for this reason that it becomes necessary to stimulate family caregivers to recognize, throughout the rehabilitation process, the shared autonomy of the caregiver-elderly binomial, and that the mode of care adopted by the caregiver is critical to helping her regain her independence from the role, provided that the elderly person is able to resume his daily activities when stimulated ${ }^{(13)}$.

It is believed that: the assessment of the level of dependence helps to determine the type of care needed, thus providing indicators for more accurate diagnosis and recognition of care needs ${ }^{(7)}$; the education of the family members about the care of dependent elderly is beneficial and can avoid new hospital admissions $^{(9)}$; the recovery of functional independence after proximal femoral fracture is associated with the absence of dementia, an age less than 85 years, and the ability to ambulate and perform activities of daily living (ADLs) and instrumental activities of daily living (IADLs) without support ${ }^{(8-9)}$. Therefore, this study had as its objectives:

a. To verify if the mode of care adopted by family caregivers positively favored recovery of functional independence in the elderly, with and without the presence of nervous system disease and/or mental and behavioral disorders;

b. To verify if these diseases negatively interfered with the functional independence of the elderly who were postoperative for a proximal femoral fracture.

\section{METHOD}

This was a transversal study, conducted in the Hospital das Clínicas of Botucatu (HC), São Paulo, Brazil, a major public institution linked to the regional SUS. The study was conducted from November of 2011 to October of 2012, in accord with the Brazilian Resolution 196/96 (National Council of Health, Resolution 196/96) (14). It was approved by the Committee on Ethics in Research (CEP) (CEP Protocol 3967/2011) and signature of the Terms of Free and Informed Consent was obtained from the elderly individual and the family caregiver. For inclusion, the elderly subjects in the study were identified in the surgical center, as those who had surgery on the proximal femur, which occurred due to a low intensity fall. Data collection was subsequently performed at the outpatient orthopedic clinic, when they returned for surgical follow-up, at which time the form designed by the researchers was administered. Surgical and anesthetic information was verified in the medical record.

The instruments for data collection were administered to some subjects to assess comprehension and, consequently, to make adjustments; these individuals were excluded from the sample. For those who did not comply with their scheduled appointment, we conducted home visits, after scheduling these by telephone and receiving the consent of the elderly and their caregivers.

The observed variables were:

- Independent variables: characteristics of the elderly individual, the family caregiver, the fall and surgery, presence of a nervous system disease, and/or mental and behavioral disorders classified within the International Classification of Diseases - ICD 10 (No/Yes), ambulation by the elderly person incentivized by the caregiver $(\mathrm{No} /$ Yes), caregiver encouraged elderly person to provide self-care (No/Yes), caregiver stimulated the elderly person to undertake leisure activity ( $\mathrm{No} / \mathrm{Yes})$;

- Outcome variable: functional independence.

The encouragement of the elderly regarding ambulation, self-care and leisure (Yes/No) was evaluated using the theoretical concept of Bocchi and Angelo ${ }^{(13)}$. The incentive for movement and ambulation was considered to be present when the caregiver reported that the elderly person used every room in the house, moving around with or without support, did not remain lying or sitting most of the time in their room, and performed physical therapy when indicated by the physician. To encourage self-care, the caregiver should say that the elder 
was encouraged to lather up in the shower, wash his hair or perform bathing independently, combing hair, brushing teeth, to perform eliminations on the toilet, not using diapers except if related to prior urinary incontinence. In stimulating leisure, the caregiver was asked about the habits of the elder before the fracture. To be considered yes, the caregiver should answer that in the last month he visited or received visits from friends and other family members, went to the supermarket, got out of the car to walk, went to church, watched television and/or returned to doing activities that he liked, and that activities were performed using the arms (crochet, knitting, games and helping with household activities).

For the assessment of functional independence, the Functional Independence Measure (FIM), a multidimensional, translated instrument validated for Brazilian Portuguese ${ }^{(15)}$, which has as its primary objective to quantitatively evaluate the burden of care demanded by a person to perform a series of motor and cognitive tasks of daily living. In other words, it seeks to assess the individual's ability and level of assistance needed for performing activities ${ }^{(15-16)}$. These activities are divided into two broad domains: the motor (self-care, sphincter control, mobility and locomotion) and the cognitive (communication and social cognition) and receives a score of one (total dependence) to seven (complete independence), as well as the total score that ranges from 18 (high dependence) to 126 (complete independence) ${ }^{15-}$ 16). The patient describes how each task is accomplished and the evaluator completes the scoring, according to the protocol for the application of the instrument. The caregiver can assist in the description of the task performed, including indicating how much help the patient requires.

The study included individuals $\geq 60$ years, undergoing proximal femoral surgery due to low-impact trauma and who received medical clearance to walk for at least one month, according to the protocol of the institution and their respective family caregivers. Data collection took place, then, in the second month in which the elderly were ambulating. Excluded from the study were elderly who had a second fracture, those who did not walk before the fracture, and those who were cared for by paid or formal caregivers.

A model of linear regression with Gamma response was adjusted to account for the functional independence score, according to the independent variables, due to the asymmetry of the distribution of scores of functional independence. The regression model with Gamma response is one of the models adequate for results that assume positive values with asymmetric distribution.

\section{RESULTS}

During the study period, 115 elderly underwent proximal femoral surgery due to a fall from a standing height. Eighteen died in the first two months after surgery, three lived in a nursing home, two received care from paid caregivers, one had fractures in both femurs, and one could not walk prior to the surgery. The sample was then composed of 89 elderly subjects (Table 1) and their family caregivers (Table 2). There was a greater prevalence of elderly females $(67.4 \%)$, aged 80 years or older, with modified/full independence (38.2\%).
Table 1 - Sociodemographic characteristics and dependency of the postoperative elderly for proximal femoral fracture

\begin{tabular}{llr}
\hline Variables & $\mathbf{n}$ & \multicolumn{1}{c}{$\%$} \\
\hline Sex & & \\
$\quad$ Feminine & 60 & 67.4 \\
$\quad$ Masculine & 29 & 32.6 \\
Age (years) & & \\
$\quad 60$ - 69 & 18 & 20.2 \\
70 - 79 & 30 & 33.7 \\
$\geq 80$ & 41 & 46.1 \\
Maximum/Moderate Dependency & 21 & 23.6 \\
Minimal/Supervision & 34 & 38.2 \\
Modified/Complete Independence & 34 & 38.2 \\
FIM Total* & 92 & $(25-125)$ \\
FIM Motor* & 69 & $(16-91)$ \\
FIM Cognitive* & 25 & $(5-35)$ \\
\hline
\end{tabular}

Note:

*Summary in median (minimum - maximum)

FIM: Functional Independence Measure

Table 2 - Sociodemographic characteristics of family caregivers and the type of incentive offered to the elderly who were postoperative for proximal femoral fracture

\begin{tabular}{|c|c|c|}
\hline Variables & $\mathbf{n}$ & $\%$ \\
\hline \multicolumn{3}{|l|}{ Sex } \\
\hline Feminine & 68 & 76.4 \\
\hline Masculine & 21 & 23.6 \\
\hline \multicolumn{3}{|l|}{ Age (years) } \\
\hline$<60$ & 66 & 74.2 \\
\hline$\geq 60$ & 23 & 25.8 \\
\hline \multicolumn{3}{|l|}{ Kinship } \\
\hline Child & 57 & 64.0 \\
\hline Partner & 11 & 12.3 \\
\hline Grandchild & 5 & 5.6 \\
\hline Niece/Nephew & 5 & 5.6 \\
\hline Daughter/Son-in-law & 5 & 5.6 \\
\hline Others & 6 & 6.9 \\
\hline \multicolumn{3}{|l|}{ Years of study } \\
\hline$<1$ year & 2 & 2.2 \\
\hline $1-5$ years & 36 & 40.5 \\
\hline $6-9$ years & 13 & 14.6 \\
\hline$\geq 10$ & 38 & 42.7 \\
\hline \multicolumn{3}{|c|}{ Incentive of elderly mentioned } \\
\hline Movement & 61 & 68.2 \\
\hline Self-care & 60 & 67.4 \\
\hline Leisure & 42 & 47.2 \\
\hline
\end{tabular}


Table 3 - Gamma regression model adjusted to explain functional dependence of the elderly postoperative for proximal femoral fracture, in terms of incentives they received, gender, age and presence of nervous system disease or mental and behavioral disorders

\begin{tabular}{lrrrr}
\hline Variables & $\beta$ & ep & p value & $\mathbf{C l}(\boldsymbol{\beta} ; \mathbf{9 5} \%)$ \\
\hline Intercept & 118.5 & 20.7 & $<0.001$ & $(77.9-159.1)$ \\
Masculine gender & 0.1 & 4.9 & 0.989 & $(-9.6-9.7)$ \\
Age & -0.7 & 0.3 & 0.009 & $(-1.2--0.2)$ \\
Incentivized for self-movement & 18.9 & 7.5 & 0.012 & $(4.2-33.5)$ \\
Incentivized for self-care & 12.8 & 7.6 & 0.093 & $(-2.1-27.8)$ \\
Incentivized for leisure & 11.5 & 5.3 & 0.031 & $(1.1-21.9)$ \\
Nervous system disease or mental and behavioral disorders. & -20.5 & 4.5 & $<0.001$ & $(-29.3--11.7)$ \\
\hline
\end{tabular}

Note:

$\beta=$ magnitude of the effect of each variable contained in the model about the level of dependency.

Table 4 - Comparison among elderly with and without nervous system disease or mental and behavioral disorders, in relationship to the Functional Independence Measure dimensions and domains

\begin{tabular}{|c|c|c|c|c|}
\hline FIM & $\begin{array}{r}\text { General } \\
(N=89)\end{array}$ & $\begin{array}{l}\text { Without nervous system } \\
\text { disease or mental and } \\
\text { behavioral disorders. } \\
(n=60)\end{array}$ & $\begin{array}{l}\text { With nervous system } \\
\text { disease or mental and } \\
\text { behavioral disorders. } \\
\qquad(\mathrm{n}=29)\end{array}$ & p value \\
\hline Self-Care & $33(9-42)$ & $36(9-42)$ & $26(10-42)$ & 0.009 \\
\hline Feeding & $7(3-7)$ & $7(3-7)$ & $7(3-7)$ & $<0.001$ \\
\hline Personal hygiene & $5(1-7)$ & $5,5(1-7)$ & $4(2-7)$ & 0.039 \\
\hline Bathing (washing the body) & $5(1-7)$ & $6(1-7)$ & $4(2-7)$ & 0.01 \\
\hline Dressing oneself above the waist & $5(1-7)$ & $6(1-7)$ & $4(1-7)$ & 0.004 \\
\hline Dressing oneself below the waist & $5(1-7)$ & $5(1-7)$ & $4(1-7)$ & 0.037 \\
\hline Use of the toilet & $6(1-7)$ & $6(1-7)$ & $4(1-7)$ & 0.057 \\
\hline Sphincter control & $12(2-14)$ & $14(2-14)$ & $12(2-12)$ & 0.22 \\
\hline Control of urine & $6(1-7)$ & $7(1-7)$ & $6(1-7)$ & 0.22 \\
\hline Control of feces & $7(1-7)$ & $7(1-7)$ & $6(1-7)$ & 0.525 \\
\hline Mobility/Transfers & $15(3-21)$ & $16(3-21)$ & $12(3-12)$ & 0.017 \\
\hline Bed, chair, wheelchair & $5(1-7)$ & $5(1-7)$ & $4(1-7)$ & 0.062 \\
\hline Toilet & $5(1-7)$ & $5(1-7)$ & $4(1-7)$ & 0.013 \\
\hline Bath or shower & $5(1-7)$ & $5(1-7)$ & $4(1-7)$ & 0.007 \\
\hline Locomotion & $6(2-14)$ & $7(2-14)$ & $5(2-14)$ & 0.176 \\
\hline Walking/wheelchair & $4(1-7)$ & $4(1-7)$ & $4(1-7)$ & 0.401 \\
\hline Stairs & $1(1-7)$ & $1(1-7)$ & $1(1-7)$ & 0.139 \\
\hline Communication & $10(2-14)$ & $12(6-14)$ & $8(2-14)$ & $<0.001$ \\
\hline Comprehension & $5(1-7)$ & $6(3-17)$ & $4(1-7)$ & $<0.001$ \\
\hline Communication & $5(1-7)$ & $6(3-7)$ & $4(1-7)$ & $<0.001$ \\
\hline Social Cognitive & $15(3-21)$ & $16(8-21)$ & $9(3-19)$ & $<0.001$ \\
\hline Social Interaction & $5(1-7)$ & $6(2-7)$ & $4(1-7)$ & $<0.001$ \\
\hline Problem resolution & $4(1-7)$ & $5(1-7)$ & $3(1-7)$ & 0.001 \\
\hline Memory & $5(1-7)$ & $6(1-7)$ & $3(1-6)$ & $<0.001$ \\
\hline FIM Motor & $69(16-91)$ & $74(16-91)$ & $49(19-91)$ & 0.023 \\
\hline FIM Cognitive & $25(5-35)$ & $28.5(14-35)$ & $18(5-33)$ & $<0.001$ \\
\hline FIM Total & $92(25-125)$ & $100.5(41-125)$ & $66(25-117)$ & 0.001 \\
\hline \multicolumn{5}{|l|}{ Level of Dependency } \\
\hline Maximum dependency & $21(23.6 \%)$ & $11(18.3 \%)$ & $10(34.5 \%)$ & \\
\hline Minimum dependency & $34(38.2 \%)$ & $20(33.3 \%)$ & $14(48.3 \%)$ & $0.082^{\mathrm{b}}$ \\
\hline Modified independence & $34(38.2 \%)$ & $29(48.3 \%)$ & $5(17.2 \%)$ & \\
\hline
\end{tabular}

Note:

FIM: Functional Independence Measure

aMann-Whitney

${ }^{b}$ Chi-squared 
As for family caregivers, females also predominated (76.4\%), with significant inclusion of males in performing the role $(23.6 \%)$ and elders caring for elders (25.8\%). Regarding the incentive mentioned by caregivers, it was observed that $68.8 \%$ encouraged movement, $67.4 \%$ self-care, and $47.2 \%$ leisure.

According to the model adjusted to explain the functional dependence of the elderly, it was found that they lost 0.7 points per year lived; in the case of presenting a nervous system disease or mental and behavioral disorder, that loss increased to 20.5 points. On the other hand, the intervention of the informal caregiver to encourage the elderly made points gains on the FIM of 18.9, 12.8 and 11.5, for movement, self-care and leisure, respectively (Table 3 ). Although self-care was not found to be significant $(p=0.093)$ in relationship to the scores of functional independence, it showed a mathematical difference. The importance of the role of these caregivers postoperatively with regard to incentives for the elderly should then be considered. Sex and age did not correlate with functional independence.

The presence of diseases in the nervous system and mental and behavioral disorders were related to functional independence. Table 4 shows the comparison of the FIM items in these groups of patients. Only the sphincter control and locomotion domains were not statistically related, although the elderly with diseases of the nervous system and mental and behavioral disorders presented lower scores when compared to those who were free of these diseases. The elderly were classified as: $23.6 \%$ with maximum or moderate dependence, $38.2 \%$ with minimal dependence or supervision, and $38.2 \%$ with modified or complete independence.

\section{DISCUSSION}

Regarding caregivers, females predominated (76.6\%), with a mean age of 50 years, ranging between 22-75 years, and $25.8 \%$ were elderly. The literature suggested that care of the elderly who are postoperative for proximal femoral surgery has been provided by a female family member ${ }^{(9-10)}$ and highlighted the role of the partner ${ }^{(9)}$ and of other elderly people caring for elderly ${ }^{(17)}$. These individuals, many times, have the same vulnerability to falls. In this study, there was a predominance of daughters as caregivers, corroborating research that also found that $64 \%$ of the elderly are cared for by their children), followed by spouse $(12.4 \%)$, grandchildren (5.6\%) and siblings $(4.5 \%)$. However, the inclusion of male caregivers is emphasized, a fact already revealed in a recent research conducted in Portugal ${ }^{(18)}$. Perhaps due to the scarcity of a female caregiver in the family, men have been obliged to assume the role.

In the present study, $23.6 \%$ were classified by the FIM with maximum/moderate dependence, showing how important families are in the recovery of functional independence of the elderly. The phase of recovery includes different scenarios and arrangements of health care, with the caregivers recognizably engaged throughout the trajectory ${ }^{(5)}$. Elderly patients undergoing proximal femoral surgery require long-term care, due to disabling complications, thrusting them into dependence on their families ${ }^{(5,19)}$. Currently the home is perceived as an environment in which dependent individuals, elderly or otherwise, are able to maintain some stability and quality of life, and the experience of caring at home is increasingly common in the family context ${ }^{(18)}$, but it takes care to substantiate that it happens properly, lessening the burden on the family caregiver.

This study showed that regardless of the presence of nervous system diseases and mental and behavioral disorders, the elderly had low scores in the domain of locomotion/gait. Total or partial physical disability strikes after injury: about $50 \%$ of patients are bedridden or wheelchair bound, and $25-35 \%$ of those who can return home require caregivers or need an assistive mobility device ${ }^{(20)}$. A national study, which evaluated 70 patients who underwent partial hip arthroplasty, found worsening of walking ability in $33 \%$ of the cases ${ }^{(21)}$. The ability to ambulate in the elderly postoperative for transtrochanteric fractures was the object of study, which showed worsening after a year of the surgical procedure. In addition, 43 patients $(82.7 \%)$ did not require assistance with ambulation before fracture and post-fracture, 23 patients (44.2\%) maintained their ability to ambulate without assistance. Six (11.5\%) patients did not recover their ability to walk after the fracture ${ }^{(22)}$.

This completion of this study showed the positive effect of incentives for the movement and leisure scores of functional independence in the elderly, signaling the importance of empowering families for care in preparation for discharge and the rehabilitation process at home. A Cuban study showed that members of the healthcare team who performed this type of intervention for relatives of elderly dependent individuals, realized that, before the intervention, the entire family had inadequate knowledge about patient care and the caregiver, and then after, $85(48 \%)$ responded adequately ${ }^{(23)}$. Elderly whose caregivers reported the need for information about care were more likely to regain their abilities to walk than those who reported no such need ${ }^{(11)}$.

The literature recommends educational interventions with caregivers. We need to encourage caregivers and the elderly, since the recovery of functional independence can be slow and not happen. A study evaluating the functional independence of elderly with fracture, at admission, discharge, and after a month at home observed considerable increase in mean values of total and motor FIM at discharge compared to admission, however, when they verified the values achieved in home, there was a decrease in the values of total FIM, compared to the values at the time of discharge. The decline following the elderly at home could be explained by the low achievement level of physiotherapeutic monitoring; by protectionism of the family that performed activities for the elder, considering him unable to perform them; performing activities for them as a way to express zeal and affection for the convalescing individual; by their own home that impeded mobility and performance of their activities ${ }^{(24)}$. A study that analyzed the perceptions of the elderly and their families in discharge planning highlighted the desire of these elders to remain in the home with their families, to regain their independence, versus the difficulties of the family in performing care and the need to be involved in the decisions of the elderly.

In this study, the elderly cohabitated in average of two people, varying from those living alone to those who lived 
with six other people. It is known that sharing the care can be beneficial to the elderly and caregivers. Research, which characterized 72 caregivers of patients with alterations, found the majority lived with the elder, had a close relationship with him, and did not have help from professionals. Moreover, they predominantly performed activities alone, which certainly influenced the quality of care ${ }^{(25)}$.

In this research, diseases of the neurological system and mental and behavioral disorders were significantly correlated with the scores of the FIM. It is known that these diseases cause a reduction in physical capacity, causing effects on postural control, generally affecting the dynamic equilibrium, and therefore become a risk factor for falls ${ }^{(1,23)}$. A comparison of the FIM scores of the elderly with and without disease in these systems was also significant in the domains of self-care, mobility/transfer, communication and social cognitive. This study found that older people with diseases in these systems also presented lower balance scores, and this was statistically associated with the scores of functional independence, which certainly shows how this population is vulnerable to falls and their consequences, and therefore require the direct care of their caregivers.

The presence of diseases in the nervous system and mental and behavioral disorders showed a negative interference in the FIM scores, significantly correlated. These data suggest that these patients constitute the first group of choice for the prevention of falls. It is known that these diseases cause a reduction in physical capacity, which may cause effects on postural control in general, affecting dynamic equilibrium, a risk factor for further falls ${ }^{(1,23)}$.

A study that estimated the prevalence of home care provided to 598 elderly showed that support programs may be directed to caregivers and that special attention should be aimed at individuals with the same characteristics of those that presented the greatest demands for home care: advanced age, low education and functional disability for $\mathrm{ADLs}^{(26)}$. The literature also pointed to the lack of motivation, caregiver overprotection and also, the psychiatric conditions such as depression, anxiety and distress were factors that might contribute to the imbalance of the normal relationship between rest and physical activity, causing physiological and biochemical changes in virtually all organs ${ }^{(13)}$. Recent research pointed to the need for further investigations, considering cognitive dysfunction and proximal femoral fractures in the elderly, both because of the relevance of the issue in addition to the lack of scientific evidence ${ }^{(27)}$.

It was considered that the care provided at home is continuing care provided by the nursing team, with this professional also responsible for training and support for families. Their role is not only to guide, rather it is necessary to know the reality of each elder and to develop individualized planning that is shared between professionals and caregivers. The need to monitor the caregiver-elder binomial is recognized, not only when they return to the health system, but also within their homes. This represents a path to be taken by the Family Health Strategy and health professionals that assist this population in the community.

Limitations of this study include: lack of direct observation of the stimuli performed, with a reliance on the reports of caregivers; using an quantitative instrument that was not validated for the evaluation of the mode of care; and, lack of knowledge regarding the pre-fracture FIM scores.

One of the contributions of this study is to show that, although the elderly with diseases of the nervous system and mental and behavioral disorders present progress well below those who were free from such comorbidities when they undertake the rehabilitation process for proximal femoral fracture, it is understood that they also deserve investments by the rehabilitation team, to provide the opportunity to progress within their limitations.

\section{CONCLUSION}

Regardless of gender, every year there is a reduction of functional independence scores, but the effect of an incentive is larger than the negative effect of aging. It is recommended that caregivers incorporate in the care of the elderly the incentive for movement and ambulation, self-care and leisure activities, especially those elderly with diseases in the nervous system and mental and behavioral disorders, who presented lower FIM scores when compared to patients without these diseases.

\section{FUNDING}

Fundação de Amparo à Pesquisa do Estado de São Paulo (Support Foundation of São Paulo Research) - FAPESP - Process 2012/09618-4.

\section{REFERENCES}

1. Fabrício SCC, Rodrigues RAP, Costa Junior ML. Falls among older adults seen at a São Paulo State public hospital: causes and consequences. Rev Saúde Pública [Internet]. 2004 [cited 2014 Dec 10];38(1):93-9. Available from: http://www. scielo.br/pdf/rsp/v38n1/en_18457.pdf

2. Coutinho ESF, Bloch KV, Rodrigues LC. Characteristics and circumstances of falls leading to severe fractures in elderly people in Rio de Janeiro, Brazil. Cad de Saúde Pública [Internet]. 2009 [cited 2014 Dec 10];25(2):455-9. Available from: http://www.scielo.br/pdf/csp/v25n2/24.pdf

3. Bongue B, Dupré C, Beauchet Ó, Rossat A, Fantino B, Colvez $A$. A screening tool with five risk factors was developed for fall-risk prediction in community-dwelling elderly. J Clin Epidemiol [Internet]. 2011 [cited 2014 Dec 10];64(10):115260. Available from: http://www.sciencedirect.com/science/ article/pii/S0895435611000114

4. Demura S, Sato S, Shin S, Uchiyama M. Setting the criterion for fall risk screening for healthy community-dwelling 
elderly. Arch Gerontol Geriatr [Internet]. 2011 [cited 2014 Dec 10];54(2):370-3. Available from: http://www.sciencedirect.com/science/article/pii/S016749431100094X

5. Shawler C. The empowerment of older mothers and daughters: rehabilitation strategies following a hip fracture. Geriatr Nurs [Internet]. 2006 [cited 2014 Dec 10];27(6):3717. Available from: http://www.sciencedirect.com/science/ article/pii/S019745720600303X

6. Bortolon PC, Andrade CLT, Andrade CAF. [Characteristics of hospital admissions in the Unified National Health System for osteoporotic hip fracture in elderly people in Brazil, 2006-2008]. Cad Saúde Pública [Internet]. 2011 [cited 2014 Dec 10];27(4):733-42. Available from: http://www. scielo.br/pdf/csp/v27n4/12.pdf Portuguese

7. Araújo I, Paúl C, Martins M. Living older in the family context: dependency in self-care. Rev Esc Enferm USP [Internet]. 2011 [cited 2014 Dec 10];45(4):869-75. Available from: http://www.scielo.br/pdf/reeusp/v45n4/en_v45n4a11.pdf

8. Nardi EFR, Oliveira MLF. Significado de cuidar de idosos dependentes na perspectiva do cuidador familiar. Ciênc Cuidado Saúde [Internet]. 2009 [cited 2014 Dec 10];8(3):428-35. Available from: http://eduem.uem.br/ojs/ index.php/CiencCuidSaude/article/viewArticle/9025

9. Lin PC, Hung SH, Liao MH, Sheen SY, Jong SY. Care nee$\mathrm{ds}$ and level of care difficulty related to hip fractures in geriatric populations during the post-discharge transition period. J Nurs Res [Internet]. 2006;14(4):251-60. Available from: http://www.ncbi.nlm.nih.gov/pubmed/17345754

10. Baptista BO, Beuter M, Girardon-Perlini NMO, Brondani CM, Budó MLD, Santos NO. [Overload of family caregiver at home: an integrative literature review]. Rev Gaúcha Enferm [Internet]. 2012 [cited 2014 Dec 10];33(1):14756. Available from: http://www.scielo.br/pdf/rgenf/v33n1/ a20v33n1.pdf Portuguese

11. Shyu YIL, Chen MC, Liang J, Tseng MY. Trends in health outcomes for family caregivers of hip-fractured elders during the first 12 months after discharge. J Adv Nurs [Internet]. 2012 [cited 2014 Dec 10];68(3):658-66. Available from: http://onlinelibrary.wiley.com/doi/10.1111/j.1365-2648.2011.05778.x/epdf

12. Lin P-C, Lu C-M. Psychosocial factors affecting hip fracture elder's burden of care in Taiwan. Orthop Nurs [Internet]. 2007 [cited 2014 Dec 10];26(3):155-61. Available from: http://www.ncbi.nlm.nih.gov/pubmed/17538469

13. Bocchi SCM, Angelo M. Interaction between stroke survivors and family caregivers: shared autonomy. Cienc Saúde Coletiva [Internet]. 2005 [cited 2014 Dec 10];10(3):72938. Available from: http://www.scielo.br/pdf/csc/v10n3/ a29v10n3.pdf

14. Conselho Nacional de Saúde. Resolução 196/96. (1996). Diretrizes e normas regulamentadoras de pesquisa envolvendo seres humanos. 1996. Brasília: Ministério da Saúde.

15. Riberto M, Miyasaki HM, Jucá SHH, Sakamoto H, Pinto PPN, Battistella LR. Validação da versão brasileira da Medida de Independência Funcional. Acta Fisiátr [Internet]. 2004 [cited 2014 Dec 10];23(3):57-60. Available from: http://www.unifra.br/professores/anabonini/ Valida $\%$ C3\%A7\%C3\%A30\%20Brasileira \%20MIF.pdf
16. Riberto M, Miyazaki MH, Jorge Filho DJ, Sakamoto H, Battistella LR. Reprodutibilidade da versão brasileira da Medida de independência funcional. Acta Fisiatr [Internet] 2001 [cited 2014 Dec 10];8(1):45-52. Available from: http://www. actafisiatrica.org.br/detalhe_artigo.asp?id = 322

17. Rodrigues SLA, Watanabe HAW, Derntl AM. A saúde de idosos que cuidam de idosos. Rev Esc Enferm USP [Internet]. 2006 [cited 2014 Dec 10];40(4):493-500. Available from: http://www.scielo.br/pdf/reeusp/v40n4/v40n4a06.pdf

18. Gonçalves LHT, Costa MAM, Martins MM, Nassar SM, Zunino R. The family dynamics of elder elderly in the context of Porto, Portugal. Revista Latino-Am Enferm [Internet]. 2011 [cited 2014 Dec 10];19(3):458-66. Available from: http://www.scielo.br/pdf/rlae/v19n3/03.pdf

19. Li HJ, Shyu YIL. Coping processes of Taiwanese families during the postdischarge period for an elderly family member with hip fracture. Nurs Science Quarterly [Internet]. 2007 [cited 2014 Dec 10];20(3):273-9. Available from: http://nsq.sagepub.com/content/20/3/273.abstract

20. Silveira VAL, Medeiros MMC, Coelho-Filho JM, Mota RS, Noleto JCS, Costa FS, Pontes FJO et al. Incidência de fratura do quadril em área urbana do Nordeste brasileiro. Cad Saúde Pública [Internet]. 2005 [cited 2014 Dec 10];21(3):907-12. Available from: http://www.scielosp.org/pdf/csp/v21n3/25.pdf

21. Ono NK, Lima GDA, Honda EK, Polesello GC, Guimarães RP, Ricioli JW. Artroplastia parcial no tratamento das fraturas do Colo do fêmur. Rev Bras Ortop [Internet]. 2010 [cited 2014 Dec 10];45(4):382-8. Available from: http:// www.scielo.br/pdf/rbort/v45n4/a07v45n4.pdf

22. Guimaraes FAM, Lima RR, Souza AC Livani B, Balangero WD. Avaliação da qualidade de vida em pacientes idosos um ano após o tratamento cirúrgico de fraturas transtrocanterianas do fêmur. Rev Bras Ortop [Internet]. 2011 [cited 2014 Dec 10];46 suppl 1:48-54. Available from: http:// www.scielo.br/pdf/rbort/v46s1/12.pdf

23. Megret CA, Naranjo AM, Fong GY. Educación a familiares sobre el manejo del adulto mayor dependiente. Rev Cubana Enferm [Internet]. 2002 [cited 2014 Dec 10];18(1):43-9. Available from: http://bvs.sld.cu/revistas/ enf/vol18_01_02/enf08102.htm

24. Monteiro CR, Faro ACM. Functional evaluation of aged with fractures at hospitalization and at home. Rev Esc Enferm USP [Internet]. 2010 [cited 2014 Dec 10];44(3):719-24. Available from: http://www.scielo.br/pdf/reeusp/v44n3/en_24.pdf

25. Santos AA, Pavarini SCL. Perfil dos cuidadores de idosos com alterações cognitivas em diferentes contextos de vulnerabilidade social. Esc Anna Nery [Internet] 2010 [cited 2014 Dec 10];14(3):496-503. Available from: http://www. scielo.br/pdf/ean/v14n3/v14n3a10.pdf

26. Del Duca GF, Thume E, Hallal PC. Prevalence and factors associated with home care among older adults. Rev Saúde Pública [Internet]. 2011 [cited 2014 Dec 10];45(1):113-20. Available from: http://www.scielo.br/pdf/rsp/v45n1/en_1913.pdf

27. Chaudhry H, Devereaux PJ, Bhandari M. Cognitive Dysfunction in Hip Fracture Patients. Clin North Am Orthop [Internet]. 2013 [cited 2014 Dec 10];44(2):153-62. Available from: http://www.sciencedirect.com/science/article/ pii/S0030589813000047 